\title{
Razlike u stavovima osoba zdravstvene i nezdravstvene struke o darivanju organa u Bjelovarsko bilogorskoj županiji
}

1 Elvira Jukić

2 Zrinka Puharić

2 Ksenija Eljuga

2 Tatjana Badrov

1 Jedinica intenzivnog liječenja Opća bolnica Bjelovar

2 Visoka tehnička škola Bjelovar, Stručni studij sestrinstva

\section{Sažetak}

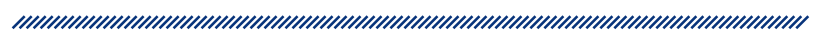

Cilj je ovog rada dobiti uvid u stavove i razlike stavova zdravstvenih te nezdravstvenih djelatnika o tematici darivanja organa te istražiti: postoji li razlika u odluci o darivanju organa ovisno o struci sudionika, ispitati koji su faktori važni zdravstvenim, odnosno nezdravstvenim djelatnicima u slučaju da odluče donirati organe, ispitati u kojim bi uvjetima zdravstveni, odnosno nezdravstveni djelatnici odbili donirati svoje organe te u kojim bi uvjetima odbili primiti organe druge osobe. U istraživanju je sudjelovalo 200 sudionika, od toga in je 100 zdravstvene struke i 100 nezdravstvene struke. Za provođenje istraživanja primijenjen je anketni upitnik sastavljen za potrebe ispitivanja stavova o tematici darivanja organa. Nije dobivena statistički značajna razlika u odluci o darivanju organa s obzirom na struku sudionika. Od faktora i uvjeta za darivanje organa važnih sudionicima ističu se hitnost stanja osobe i da osoba nije ovisničkog ponašanja, dok bi primili organe osobe neovisno o dobi, spolu, rasi i vjeri. Unatoč malom broju potpisanih donorskih kartica, najveći broj sudionika izrazio je želju za darovanjem organa, što upućuje na važnost educiranja osoba o ovoj tematici uz poticanje na potpisivanje donorske kartice, ako je to u skladu sa stavom osobe.

Ključne riječi: darivanje organa, donorska kartica, zdravstveni djelatnici

Datum primitka: 28.10.2015.

Datum prihvaćanja: 18.11.2015.

Adresa za dopisivanje:

Dr. sc. Zrinka Puharić, dr. med., viši predavač

Visoka tehnička škola, Stručni studij sestrinstva

Trg Eugena Kvaternika 4

43000 Bjelovar, Hrvatska

Tel.: 0917981653

E-pošta: zpuharic@vtsbj.hr

\section{Uvod}

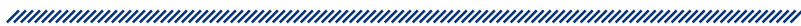

Transplantacija organa medicinski je postupak odstranjenja tkiva ili organa iz tijela osobe kako bi se oni presadili u tijelo primatelja s namjenom ponovnog uspostavljanja određenih funkcija ljudskog tijela i mogućnosti produženja ili spašavanja života primatelja. Presađivanje se može izvršiti „sa živoga” (ex vivo) ili „s umrlog” (ex cadavere) darivatelja ${ }^{1}$. Osobu koja daruje jedan ili nekoliko organa u svrhu presađivanja nazivamo dariva- 
teljem. Darivanje organa etičko je ili pravno postupanje kojim se darivatelj slaže da se medicinski postupak odstranjenja organa izvrši na njemu i presadi u tijelo druge osobe. Eksplantacija je termin koji označava uzimanje organa i tkiva preminule osobe sa svrhom liječenja pacijenata oštećenih ili uništenih organa².

Pomanjkanje organa globalni je problem transplantacijskog sustava u svijetu - napredovanje medicine i razvoj transplantacijskih kirurških metoda dovodi do rasta broja lista čekanja na presađivanje organa. Najveći je razlog tomu što je darivanje s preminulih osoba moguće provoditi tek nakon dokazane moždane smrti. No postoji dokaz da pomanjkanje organa za presađivanje nije primarno uzrokovano pomanjkanjem takvih donora, nego češće propustom u njihovu prepoznavanju, dobivanju pristanka i realizaciji eksplantacije ${ }^{3}$.

Živi je darivatelj osoba koja dobrovoljno daruje organ, tkivo ili stanice za presađivanje određenom primatelju. Darivatelj mora biti adekvatno obaviješten o prirodi i svrsi uzetog materijala te o mogućim posljedicama, odnosno rizicima koji mogu biti tjelesni i psihički. Također, nužno je obaviti određene medicinske pretrage zbog procjene zdravstvenog stanja darivatelja, kao i prikladnosti materijala koji će biti doniran. Prije provođenja dijagnostičkih postupaka potrebno je dobiti pisani pristanak darivatelja koji oni mogu i svojevoljno povući u bilo kojem trenutku4 ${ }^{4}$. Kadaverični darivatelji mogu biti preminule osobe koje su za vrijeme života izrazile pristanak na darivanje organa, tkiva ili stanica, ili preminule osobe čije obitelji daju pristanak, odnosno ne izraze protivljenje eksplantaciji organa4.

S obzirom na uzrok smrti i uvjete u kojima je nastupila, tri su tipa kadaveričnih darivatelja:

a) heart-beating (s kucajućim srcem) darivatelji s moždanom smrću

b) CPA darivatelji, odnosno darivatelji koji su umrli od kardiopulmonalnog aresta

c) non-heart-beating (s nekucajućim srcem) darivatelji ${ }^{5}$.

Organi se većinom eksplantiraju od heart-beating darivatelja s moždanom smrću, dok se tkiva uzimaju od heart-beating i non-heart-beating darivatelja. U nekim državama zabranjeno je uzimanje organa od non-heartbeating darivatelja, a to su osobe s potpunim i nepovratnim prestankom kardiorespiratornih funkcija te posljedičnom smrću mozga ${ }^{4}$. U Hrvatskoj nije prihvaćena eksplantacija organa s non-heart-beating darivatelja te nema zakona o njoj. Organizacija jedinica intenzivnog liječenja u cijelom svijetu s vrhunskom opremom i obučenim kadrom daje mogućnost umjetnog održavanja niza vitalnih funkcija bolesnika, a posljedično i mogućnost spašavanja života ili produživanja umiranja. To je dovelo do nužnosti i potrebe redefinicije pojma smrti: čovjek se može proglasiti mrtvim samo ako je njegov mozak mrtav. Znači, kriterij prestanka disanja i zatajenja srca nije relevantan jer se disanje može umjetno provoditi, kao što se i srce, kada stane, može ponekad ponovno vratiti u funkciju određenim metodama, dok se funkcija mozga nikakvim načinom ili metodom ne može zamijenití. Smrt mozga označuje se u terminima cerebralne smrti, smrti moždanog debla, kortikalne smrti, ireverzibilne smrti, prolongirane kome i slično pa iz mnogih termina i definicija slijede i različita shvaćanja smrti mozga, kao i dvojbe oko njezina utvrđivanja ${ }^{7}$. Moždana smrt, odnosno smrt osobe, može se utvrditi kad nastupi stanje nepovratnog oštećenja mozga s gubitkom funkcija hemisfera mozga, malog mozga i moždanog debla, jer je bez funkcioniranja mozga život nemoguć 6 .

Postupak utvrđivanja moždane smrti može započeti uz prethodno ispunjenje sljedećih uvjetå:

a) etiologija nepovratnog oštećenja mozga poznata je i dokumentirana nalazom CT-a

b) isključeni su reverzibilni uzroci koji mogu oponašati moždanu smrt

c) osoba je u apneičnoj komi (nema spontanih pokreta disanja).

Po ostvarenju navedenih uvjeta započinje se s kliničkim pregledom, odnosno utvrđivanjem kliničkih znakova smrti mozga:

a) izostanak reakcija zjenica na svjetlo

b) izostanak kornealnog refleksa - nema spontanog treptanja

c) podražaj $n$. trigeminusa - odsutnost reakcije na bolno podraživanje u području inervacije $n$. trigeminusa

d) izostanak okulocefalnih refleksa - oči prate pokrete glave

e) izostanak okulovestibularnih refleksa - nema pomicanja očiju

f) izostanak faringealnog refleksa

g) izostanak trahealnog refleksa

h) atonija muskulature

i) atropinski test

j) apnejski test - izostanak spontanog disanja? 
Smrt mozga, odnosno potpuni prestanak moždanih funkcija, utvrđuje se s dva uzastopna prethodno navedena klinička pregleda, s tim da se apnejski test ne izvodi tijekom drugog kliničkog pregleda ako su kod prvoga ispunjeni svi kriteriji za dijagnozu smrti mozga ${ }^{8}$. Između dva pregleda mora proći propisani najkraći vremenski razmak od tri sata za odrasle osobe i djecu stariju od 12 godina, 12 sati kod djece od dvije do 12 godina i 24 sata kod djece u dobi od dva mjeseca do dvije godine.

Nakon kliničkog pregleda nužno je provesti jedan od sljedećih parakliničkih potvrdnih testova, koji je dovoljno učiniti jedanput ${ }^{8}$ :
a) selektivna panangiografija mozga
b) transkranijska Doppler sonografija
c) perfuzijska radionuklearna scintigrafija
d) evocirani moždani potencijali
e) EEG
f) CT multislice kontrastna panangiografija.

Klinički pregled za utvrđivanje moždane smrti obavlja povjerenstvo od dva liječnika: anesteziolog i pedijatar za osobe u dobi do 12 godina te anesteziolog i neurolog ili neurokirurg i anesteziolog za osobe starije od 12 godina. Kao vrijeme smrti osobe uzima se vrijeme utvrđivanja smrti mozga te tada liječnik obustavlja sve daljnje terapijske postupke ${ }^{8}$. Sve osobe s moždanom smrću možemo smatrati potencijalnim donorima te je kod njih potrebno umjetno održavati osnovne životne funkcije, disanje i krvotok, samo kako bi se izvršila priprema uzimanja organa za transplantaciju, dok je primjena lijekova ili drugih medicinskih metoda i aktivnosti nepotrebna ${ }^{6}$. Prepoznavanje moždane smrti kod bolesnika $i$ njezino rano dokazivanje, zbog hemodinamičke nestabilnosti i nastanka infekcija, vrlo je važno za dobivanje organa za transplantaciju. Većina potencijalnih darivatelja prepozna se u prva 24 sata od prijma u JIL, dok se njih $25 \%$ ne prepozna u prvih 48 ili više sati ${ }^{9}$. Proces od utvrđivanja moždane smrti pa sve do eksplantacije organa traje od 12 do 48 sati. $U$ njemu je nužno detaljno $i$ točno pridržavanje protokola, nadzor i uključenost koordinatora u svim fazama. Zatim je potrebno napraviti evaluaciju donora i organa za transplantaciju, zadovoljiti sve medikolegalne uvjete, paziti na hemodinamičku stabilnost i obaviti razgovor s obitelji ${ }^{5}$.

Povijest transplantacije organa u svijetu započela je 1902. godine, kad su kirurzi Ullman i Carrel učinili prvu transplantaciju bubrega, odnosno eksperimentalnu transplantaciju bubrega kod psa ${ }^{10}$. Transplantacija u Hrvatskoj ima 40 godina dugu povijest, točnije prvu je transplantaciju izveo prof. dr. Vinko Frančišković sa suradnicima 1971. godine u KBC-u Rijeka, i to transplantaciju bubrega sa živog darivatelja, a s umrlog 1972. godine. Prof. dr. Josip Sokolić i suradnici učinili su prvu transplantaciju srca u Hrvatskoj 1988. u KBC-u Zagreb ${ }^{1}$, dok je 1990. doc. dr. Vuk Borčić sa suradnicima obavio prvu transplantaciju jetre, također u KBC-u Zagreb. S obzirom na to da je prva transplantacija bubrega u svijetu bila 1954. godine, a srca 1988. godine, može se vidjeti kako naši početci ne zaostaju mnogo za svjetskima. Međutim, brzi razvoj transplantacijskih kirurških tehnika i početni entuzijazam nije dugo trajao. Početni problemi s organizacijom, a i Domovinski rat onemogućili su napredak transplantacijske medicine, odnosno dolazi do prekida transplantacijskih aktivnosti. Nakon Domovinskog rata slijedi razvoj multiorganskih kirurških tehnika, tako da se 2003. godine transplantiraju bubreg-gušterača, zatim bubreg-jetra, a tanko crijevo 2007. godine. Sve standardne metode liječenja i sva klinička praksa nalaze se u pet transplantacijskih centara u Hrvatskoj. To su Klinički bolnički centar Zagreb (bubreg, srce, jetra), Klinička bolnica Merkur (jetra, gušterača, bubreg, tanko crijevo), Klinička bolnica Dubrava (srce), Klinički bolnički centar Rijeka (bubreg, jetra) te Klinička bolnica Osijek (bubreg) ${ }^{11}$. Nakon završetka Domovinskog rata Državni sabor 1999. godine donosi Rezoluciju o poticanju presađivanja organa u Hrvatskoj. Ministarstvo zdravstva tako 2000. godine imenuje nacionalnoga transplantacijskog koordinatora - liječnika koji je zaposlen u punom radnom vremenu u Ministarstvu na unaprjeđenju transplantacijskog sustava. Razdoblje od 2000. do 2010. godine praćeno je povećanjem broja darivatelja zahvaljujući uspostavljanju 24-satnog dežurstva za koordinaciju te logističku i tehničku pomoć donorskim bolnicama i transplantacijskim timovima. Sljedeća je značajna karika mreža bolničkih koordinatora - sastavljena od anesteziologa u jedinicama intenzivnog liječenja koji koordinacijski posao obavljaju dodatno, tako da je svaka bolnica dobila odgovornu osobu za prepoznavanje i realizaciju darivatelja organa. Uloga koordinatora bitna je da bi se razvio pozitivan stav zdravstvenih radnika u JIL-u, često je osoblje u JIL-u educirano za liječenje i za skrb o umirućim bolesnicima, ali ne i za skrb o darivatelju organa. Od 2007. godine Hrvatska je punopravna članica Eurotransplanta - međunarodne organizacije koja koordinira dodjelu organa između Slovenije, Austrije, Njemačke, Luksemburga, Belgije i Nizozemske. U Hrvatskoj se od 2006. godine transplantacijski postupci i priprema darivatelja plaćaju iz državnog proračuna, cjenik definira HZZO i sustav DTS, a cijene se kreću od 70.000 do 350.000 kuna $^{11}$. Preliminarno izvješće Naci- 
onalnog transplantacijskog programa za 2014. godinu govori da je tijekom 2014. godine u Eurotransplantu stopa transplantacije s umrlih darivatelja iznosila 80,5 , što nas stavlja na treće mjesto iza Austrije i Belgije. Transplantacija je u 2014. godini s umrlih darivatelja bilo 342 , od toga su najbrojniji bili bubrezi (178) te jetre (122). Provedenih transplantacija sa živih darivatelja u Hrvatskoj u 2014. godini svega je 11, od toga 10 bubrega i jedna jetra. Prema broju transplantacija bubrega na broj stanovnika Hrvatska je danas vodeća zemlja u svijetu $^{12}$. Prema podatcima preliminarnog izvješća za 2014. godinu, najveći je broj darivatelja u dobi između 16 i 55 godina, njih 55, prednjači muški spol, njih 89, te je prirodna smrt uzrok smrti u 111 slučajeva. Bolesnici koji su primljeni u JIL po preliminarnom izvještaju imaju posebnu kariku u izvješću tako da je ukupan broj umrlih u JIL-u 4153 bolesnika, od toga je potencijalnih darivatelja bilo 294 , dok ih je realizirano 146 , a od toga 39 nije transplantirano zbog nepristanka obitelji. U 2014. godini po broju transplantiranih organa na prvom je mjestu Klinička bolnica Merkur sa 113 transplantacija jetre te Klinički bolnički centar Zagreb sa 108 transplantacija bubrega ${ }^{13}$.

Svatko od nas može biti darivatelj organa i primatelj organa. Iskaz osobe o pozitivnom stavu za darivanje potpisivanje je donorske kartice koju možemo potpisati kod svojeg liječnika primarne zdravstvene zaštite, no potrebno je sa svojim stavom upoznati i ostale članove obitelji kako bismo im, u najtežim trenutcima u kojima svi mislimo da se nećemo naći, olakšali donošenje pravilne odluke. Osobe koje se protive darivanju dijelova tijela u svrhu presađivanja popunjavaju Izjavu o nedarivanju dijelova tijela poslije smrti kod svojeg liječnika primarne zdravstvene zaštite, koji je dostavlja na adresu Ministarstva, gdje koordinator originalni primjerak Izjave označava brojem i pohranjuje u arhiv Odjela.

\section{Transplantacija u Bjelovarsko- bilogorskoj županiji}

Opća bolnica Bjelovar uključena je u transplantacijski nacionalni sustav s obvezom prijavljivanja i zbrinjavanja pacijenata s dijagnosticiranom moždanom smrću kao potencijalnih darivatelja organa i tkiva. Postupak utvrđivanja moždane smrti (smrti mozga) zakonski je i stručno jasno određen i ključan u slučajevima potencijalnih darivatelja, no u bjelovarskoj se bolnici ne može u cijelosti obaviti, jer za to ne postoje sve tehničke mogućnosti. Takve bolesnike transportiramo u kliničke ustanove u Zagrebu kako bi se provela propisana dijagnostika, stoga naši pacijenti administrativno postaju donori iz tih ustanova te posljednjih godina nemamo službeno registrirane darivatelje iz OB-a Bjelovar. Darivanje organa vrlo je kompleksno, no upravo nemogućnost pune dijagnostike smrti mozga u bjelovarskoj bolnici dodatno komplicira tu aktivnost. Na liječnicima u JIL-u posebno je velik teret, zbog obitelji kojoj se priopćava krajnje loš ishod bolesnog stanja i liječenja te vjerojatna smrt mozga i koju se upoznaje s namjerom uzimanja organa. Nedovoljno informiranje i komunikacija te nerazumijevanje stanja smrti mozga i sustava darivanja organa ima dokazano negativan utjecaj na odluku obitelji, što čini drugi veliki problem u praksi, tako da se od potencijalnih darivatelja u bjelovarskoj bolnici najčešće odustaje baš zbog odbijanja obitelji. Nabavkom uređaja MSCT otvorena je mogućnost za utvrđivanje smrti mozga, a najvažnije je da se o stavu o darivanju organa razgovara u krugu obitelji ili da se potpiše donorska kartica. Treba imati na umu da samo ako ste spremni pokloniti možete očekivati da će drugi pokloniti vama, a svakom od nas organ može zatrebati već sutra.

\section{Cilj istraživanja}

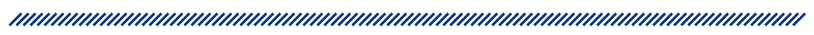

1. Utvrditi postoji li razlika u odluci o darivanju organa ovisno o struci sudionika.

2. Ispitati koji su faktori važni zdravstvenim odnosno nezdravstvenim djelatnicima za odluku od darivanju organa.

3. Ispitati kojim bi pacijentima zdravstveni odnosno nezdravstveni djelatnici odbili donirati svoje organe.

4. Ispitati u kojim bi uvjetima zdravstveni odnosno nezdravstveni djelatnici odbili primiti organe druge osobe.

5. Utvrditi postoji li razlika u informiranosti o tematici darivanja organa s obzirom na struku sudionika. 


\section{Metode istraživanja}

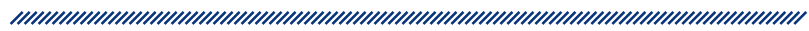

$\mathrm{U}$ istraživanju su sudjelovali medicinske sestre i tehničari Opće bolnice Bjelovar, njih ukupno 100, te osobe nezdravstvene struke koje nisu zaposlene u Općoj bolnici Bjelovar, odnosno raznih drugih struka, njih ukupno 100. Za provođenje istraživanja primijenjen je anketni upitnik sastavljen za potrebe ispitivanja stavova o tematici darivanja organa. Upitnik se sastoji od 17 pitanja, među kojima se prvi dio odnosi na općenite podatke o ispitanicima (dob, spol, stručna sprema, podatak o zdravstvenoj/nezdravstvenoj struci, vjera). Drugi dio pitanja odnosi se na podatke povezane s darivanjem organa. Anonimno anketiranje provedeno je u srpnju 2015. godine na području grada Bjelovara.

\section{Rezultati}

U istraživanju je sudjelovalo 200 sudionika, a samo ih je 34 (20 zdravstvene i 14 nezdravstvene struke) potpisalo donorsku karticu. Ukupno 140 sudionika (70 zdravstvene i 70 nezdravstvene struke) izjavilo je da bi darovali svoje organe za vrijeme života. Ukupno 164 ispitanika (84 zdravstvene i 80 nezdravstvene struke) izjavilo je da bi darovali svoje organe nakon smrti, a njih 106 (47 zdravstvene i 59 nezdravstvene struke) dozvolilo bi darivanje organa bliskih osoba koje prethodno nisu potpisale donorsku karticu. Sudionici ističu „hitnost stanja“ osobe te da osoba „nije ovisnik“ kao njima najvažnije kriterije za odluku od darivanju organa, dok ostale faktore smatraju manje važnima ili nevažnima. „Hitnost stanja“ navelo je 74 sudionika zdravstvene te 69 sudionika nezdravstvene struke kao važan faktor u odluci. Faktor „da nije ovisnik“ navelo je 60 osoba zdravstvene struke i 46 nezdravstvene struke. Prema stavovima sudionika, ostali navedeni faktori ne predstavljaju veliku važnost u odluci o darivanju organa, a posebno se ističu faktor spola i rase kao najmanje važni faktori. Većina sudionika ne odbija dati organe osobama druge vjeroispovijesti, starijoj osobi, osobi druge rase i spola te nepoznatoj osobi. Većina svih sudionika primila bi organe neovisno o navedenim faktorima. Međutim, iako u manjini, 20 sudionika zdravstvene i 24 sudionika nezdravstvene struke navodi da ne bi primili organe starije osobe, što je najizraženije u negativnoj kategoriji. Od 200 sudionika njih 129 (64,5\%) izjavljuje da je u proteklih godinu dana čulo ili čitalo o darivanju organa, od toga 67 sudionika zdravstvene i 63 sudionika nezdravstvene struke, 65 (32,5\%) nije čulo ili čitalo o navedenoj tematici u zadnjih godinu dana, dok šest sudionika (3\%) navodi odgovor "ne znam“. Od sveukupnog broja sudionika najviše $(\mathrm{N}=111)$ bi ih voljelo da ih o ovoj tematici informiraju liječnici, i to 58 sudionika zdravstvene te 53 sudionika nezdravstvene struke. Za izvor informacija o ovoj tematici osobe zdravstvene struke u najmanjoj mjeri biraju televiziju ( $N=2)$, dnevne novine $(N=0)$ te prijatelje $(\mathrm{N}=0)$, dok osobe nezdravstvene struke navode dnevne novine $(N=2)$, stručne knjige $(N=1)$ i prijatelje $(\mathrm{N}=1)$ kao najmanje korišten izvor informacija. Najveći broj sudionika, 88 zdravstvene i 92 nezdravstvene struke, sveukupno $90 \%$, smatra da u svijetu postoji tzv. crno tržište organa. Samo jedna osoba zdravstvene struke smatra da ono ne postoji, dok se ostalih 9,5\% opredijelilo za stav „ne znam“.

Statistički značajna razlika prema struci ispitanika testirana je na pitanje „Koji je organ 1971. prvi transplantiran u Hrvatskoj?“, gdje su dobiveni rezultati: $\chi^{2}=5,339$, $\mathrm{ss}=3, \mathrm{p}=0,149$. Dobiveni hi-kvadrat manji je od granične vrijednosti hi-kvadrata uz tri stupnja slobode i razinu značajnosti od $5 \%(5,339<7,81)$, što ukazuje na to da ne postoji statistički značajna razlika u odgovorima ispitanika zdravstvene i nezdravstvene struke na prethodno navedeno pitanje. Na pitanje „Koliko ljudi trenutačno čeka na transplantaciju bubrega u Hrvatskoj?“ dobiveni su rezultati: $\chi^{2}=4,516$, ss $=3, p=0,211$. Dobiveni hi-kvadrat manji je od granične vrijednosti hi-kvadrata uz tri stupnja slobode i razinu značajnosti od $5 \%$ $(4,516<7,81)$. Dobivena vrijednost ukazuje na to da ne postoji statistički značajna razlika u odgovorima ispitanika zdravstvene i nezdravstvene struke na prethodno navedeno pitanje.

\section{Rasprava}

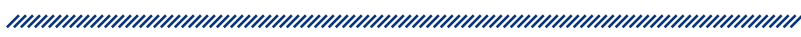

Statističkom analizom utvrđeno je da nema razlike u odluci o darivanju organa između zdravstvenih i nezdravstvenih djelatnika, odnosno struka nije varijabla koja 
utječe na spremnost osobe na darivanje organa. Što se tiče pristanaka na darivanje organa, samo je $17 \%$ ispitanika potpisalo donorsku karticu, odnosno 34 sudionika od njih 200. Hrvatska donorska kartica službeno je sredstvo za javno promicanje poklanjanja organa u svrhu liječenja. S obzirom na struku, moglo bi se očekivati da su zdravstveni djelatnici više informirani i osviješteni o ovoj tematici pa da će samim time promicati praksu potpisivanja donorskih kartica. Unatoč tome, samo je 20 od 100 ispitanih zdravstvenih djelatnika potpisalo donorsku karticu, dok je to učinilo još manje sudionika nezdravstvene struke, njih 14. Međutim, manji broj potpisanih donorskih kartica u ovom uzorku ispitanih sudionika može značiti da su informirani o činjenici da Hrvatska ima zakon tzv. pretpostavljenog pristanka, a to znači da su svi građani Republike Hrvatske mogući darivatelji ako se tijekom života nisu izjasnili da su protiv darivanja organa. Drugim riječima, osoba može biti donor i bez potpisane donorske kartice ako nije potpisala Izjavu o nedarivanju kod liječnika primarne zdravstvene zaštite. Izjave o nedarivanju upisuju se u Registar nedarivatelja pri Ministarstvu zdravlja. U prilog prethodno navedenom idu i podatci dobiveni ovim istraživanjem: $70 \%$ sudionika izjavilo je da bi darovali svoje organe za vrijeme života, dok je 82 \% izjavilo da bi darovali svoje organe nakon smrti. Vidi se velika razlika između spremnosti na darivanje organa (za vrijeme života i nakon smrti) i potpisanih donorskih kartica (14\%), što bi značilo da su ljudi voljni donirati organe iako nemaju potpisanu donorsku karticu. Prema najnovijim informacijama, broj darivatelja uvećan je za 106 \% u odnosu na 2014. godinu. Iz dobivenih rezultata vidljivo je da osobe podupiru darivanje organa, međutim uz mali broj potpisanih donorskih kartica darivanje organa i odlučivanje obitelji preminulog o tome može biti otežano. $U$ većini europskih zemalja koje imaju zakon pretpostavljenog pristanka ipak je običaj da se obitelj preminulog člana pita za dozvolu za eksplantaciju organa. Unatoč zakonu pretpostavljenog pristanka, ako se članovi obitelji preminule osobe izričito protive darivanju organa, njihova se želja poštuje. Od sudionika zahvaćenih ovim istraživanjem $53 \%$ bi dozvolilo darivanje organa bliskih osoba koje prethodno nisu potpisale donorsku karticu, od toga je $29,5 \%$ sudionika nezdravstvene struke, a 22,5\% zdravstvene struke. Ukupno $47 \%$ sudionika navodi da ne bi dozvolilo prethodno navedeno. Zbog toga je vrlo važno da osoba razgovara s bližnjima kako bi znali kakav je njezin stav o darivanju organa nakon smrti. Ako je obitelj upoznata s pozitivnim stavom preminule osobe o darivanju organa nakon smrti, većinom poštuje želju preminulog i ne protivi se eksplantaciji. Nažalost, praksa poka- zuje da članovi obitelji većinom nisu upoznati sa stavom preminuloga o ovoj temi i tada im je bitno je li osoba potpisala donorsku karticu te uglavnom poštuju stav osobe i ne protive se eksplantaciji ako je donorska kartica potpisana. Prema podatcima iz Ministarstva zdravlja, 2014. godine 39 obitelji izrazilo je nepristanak na darivanje organa njima bliske osobe ${ }^{13}$. Mogući razlog, uz nepoznavanje stava preminule osobe, može biti nerazumijevanje moždane smrti. Kako bi se to izbjeglo ili umanjilo, stručna osoba mora dodatno objasniti članovima obitelji taj pojam, prilagoditi razgovor njihovoj razini shvaćanja i prihvaćanja informacija. Obitelji je potrebno pristupiti s mnogo razumijevanja i suosjećajnosti, objasniti joj i nekoliko puta, ako je potrebno, da je njihov član mrtav i da ne postoji nikakva mogućnost da ostane živ ili da živi u vegetirajućem stanju. Ako se obitelj i dalje protivi, ne pristupa se eksplantaciji organa ${ }^{6}$. Uz to razlozi mogu biti i religijski, međutim tada ih je potrebno podsjetiti ili reći im kako gotovo sve religije potiču darivanje organa. Također, moguće je da osjećaju sumnju u sustav distribucije organa te su nepovjerljivi prema čitavom procesu transplantacije. Naime, ovim je istraživanjem pokazano kako $90 \%$ sudionika (44\% zdravstvene i $46 \%$ nezdravstvene struke) smatra da postoji crno tržište organa. Tu je opet naglašena potreba za informiranjem. Potrebno je u javnosti graditi pozitivan odnos prema darivanju, jer to predstavlja doprinos očuvanju života i zdravlja. Liječnici u tome imaju primarnu moralnu obvezu ${ }^{14}$. Ako razlozi obitelji za odbijanje darivanja organa preminule osobe nisu odraz poštivanja stava preminulog, tada se toplim pristupom, objašnjenjem i razgovorom s članovima obitelji može promijeniti njihov stav i dobiti dozvolu za eksplantaciju organa. Kao najvažniji faktor u odluci o darivanju vlastitih organa sudionici su označili da bi svoje organe dali nekome kome su hitno potrebni, i to 74 sudionika zdravstvene i 69 sudionika nezdravstvene struke. Stupanj hitnosti faktor je koji se mora poštovati pri odabiru primatelja i prema Pravilniku o kriterijima za dodjelu dijelova ljudskog tijela i vođenja nacionalne liste čekanja. Također, 60 sudionika zdravstvene struke navodi da im je važno da osoba kojoj doniraju organe ne bude ovisnik, odnosno $50 \%$ zdravstvenih djelatnika navodi da bi odbili dati organe osobi koja je ovisnik, dok nijedan drugi faktor nije naglašen kao uvjet u kojem bi odbili donirati. Većina svih sudionika primila bi organe druge osobe neovisno o navedenim faktorima. Ostale kategorije odgovora slabo su zastupljene, što govori u prilog tome da su sudionici u većini spremni donirati organe onima kojima je to potrebno, bez obzira na dob, spol, rasu i slične karakteristike, a isto tako i primiti organe druge osobe. Tako su, prema statistici, u 2014. godini 
zahvaljujući broju od 144 darivatelja 354 osobe dobile novu priliku za život ${ }^{13}$. Rezultati pokazuju da na dva pitanja o informiranosti povezana s istraživanjem nema statistički značajne razlike u odgovoru između zdravstvenih i nezdravstvenih ispitanika.

Svakako je potrebno raditi na osvještavanju građana o tematici darivanja organa i na njihovu informiranju. Od ispitanih je sudionika $64,5 \%$ u posljednjih godinu dana čulo ili čitalo o ovoj temi, dok čak $32,5 \%$ nije čulo ništa. To je dosta velik postotak s obzirom na to da je $50 \%$ sudionika zdravstvene struke. lako dnevne novine i televizija nisu prvi odabir osoba u informiranju o toj temi, smatramo da je vrlo važno da se medijima što više prenosi ideja o darivanju organa kao plemenitom činu, kao i važnost potpisivanja donorskih kartica ako je osoba voljna donirati organe. Prema anketi, 111 sudionika od njih 200 liječnika smatra poželjnim i relevantnim izvorom informacija o temi darivanja organa. Stoga bi svaki liječnik primarne zdravstvene zaštite trebao svoje pacijente kratko educirati o ovoj temi i uputiti ih na mogućnost potpisivanja donorske kartice kako bi se olakšao čitav proces darivanja organa. Ako su ljudi neupućeni i barataju s malo relevantnih informacija o darivanju organa, a istovremeno slušaju o ružnim vijestima poput „crnog tržišta organima“, očekivano je da neće potpisivati donorske kartice niti jasno izražavati želju da doniraju svoje organe. Stoga je informiranje iz raznih izvora vrlo važan faktor u čitavom procesu osvještavanja građana.

Hrvatska je, prema podatcima Eurotransplanta, prva u svijetu po broju transplantiranih jetara i bubrega $\mathrm{s}$ preminulih darivatelja, dok je druga u svijetu po broju transplantacija srca. lako najveći broj ispitanih sudionika (44 \%) smatra da oko 300 osoba čeka na transplantaciju bubrega, odnosno $30,5 \%$ smatra da je ta brojka oko 400 , istina je da na transplantaciju bubrega čeka samo 97 osoba, što je znalo samo $6 \%$ ispitanih. Na konferenciji za medije povodom Nacionalnog dana darivanja i presađivanja organa i tkiva ove godine rečeno je i da 24 osobe trebaju novo srce, dok 68 osoba mora dobiti novu jetru. Unazad pet godina lista čekanja smanjila se za $37 \%$ te hrvatski pacijenti na presađivanje bubrega čekaju u prosjeku manje od godinu dana, na presađivanje jetre 16 dana, a srca 70 dana. To su nevjerojatni podatci koji potkrepljuju činjenicu da je hrvatska transplantacijska medicina vodeća u svijetu te da je Svjetska zdravstvena organizacija Hrvatsku imenovala Regionalnim zdravstvenim centrom za razvoj programa darivanja i transplantacije organa u okviru Zdravstvene mreže zemalja jugoistočne Europe.

\section{Zaključak}

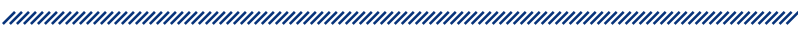

Rezultati rada pokazuju da nema razlike u mišljenjima i stavovima zdravstvenih i nezdravstvenih djelatnika u odluci o darivanju organa, kao i ostalim stavovima. Rezultati pokazuju da su ljudi voljni donirati organe za vrijeme života (70 \%) i nakon smrti (82\%), međutim samo je njih $14 \%$ potpisalo donorsku karticu koja je u Hrvatskoj jedino sredstvo kojom osoba može izraziti solidarnost, dobročinstvo i društvenu odgovornost poklanjanjem svojih organa nakon smrti. Također, naglašena je važnost komunikacije i upoznavanja najbližih sa stavom o poklanjanju organa nakon smrti, jer u suprotnom obitelj često nakon smrti bližnjeg odbije eksplantaciju organa zbog nepoznavanja stava ili ima teškoće u odlučivanju, što otežava čitav proces darivanja organa. Ovim upitnikom nije zahvaćeno pitanje koliko su bližnji informirani o njihovu stavu, što bi bilo zanimljivo za saznati i usporediti, ali svakako se naglašava važnost već navedenog, kao i potpisivanja donorskih kartica, ako je osoba voljna donirati organe. Iako je Hrvatska vodeća u svijetu po broju darivatelja organa na milijun stanovnika (prva po broju presađivanja jetre i bubrega te druga po broju transplantacije srca), potreba za organima za transplantaciju sve je veća i u budućnosti će biti potrebno sve više darivatelja. 


\section{Literatura}

1. Tomašević L, Pelčić G. Etičko-kršćanski stavovi o transplantaciji organa. Služba Božja. 2008;48(3):229-260.

2. Zavod za javno zdravstvo Primorsko-goranske županije. Doniranje organa [internet]. Dostupno na: http://www. zzjzpgz.hr/nzl/78/organi.htm (pristupljeno 02.09.2015.)

3. Matesanz R, Miranda B. A decade of continuous improvement in cadaveric organ donation: the Spanish model. Journal of Nephrology. 2002;15(1):22-8.

4. Hrvatska donorska mreža. Vodič za kvalitetu i sigurnost u transplantaciji organa, tkiva i stanica [internet]. Dostupno na: http://www.hdm.hr/knjige/vodic.pdf (pristupljeno 30.09.2015.)

5. Krstulović B. Detekcija, selekcija i evaluacija donora. Davatelj organa i moždana smrt [internet]. Dostupno na: http://www.hdm.hr/tecaj/HTML/DAVATELJ.htm (pristupljeno 02.09.2015.)

6. Bačić A. Određivanje nastanka smrti, transplantacija organa. Crkva u svijetu. 1998;33(l):53-61.

7. Pelčić G, Šegota I, Frković A, Tomašević L, Pelčić G, Mršić Pelčić J, Gjuran Coha A. Presađivanje organa i shvaćanje smrti. Društvena istraživanja. 2007;16(92):1287-1304.

8. Pravilnik o načinu, postupku i medicinskim kriterijima za utvrđivanje smrti osobe čiji se dijelovi tijela mogu uzimati radi presađivanja. Narodne novine. 2006;3:120. Dostupno na: http://www.propisi.hr/print.php?id=3558 (pristupljeno 05.09.2015.)

9. Žgrablić N. Dijagnostika moždane smrti. Davatelj organa i moždana smrt [internet]. Dostupno na: http:// www.hdm.hr/tecaj/HTML/DAVATELJ.htm (pristupljeno 02.09.2015.)

10. Markić D, Valenčić M, Maričić A, Španjol J, Rački S, Fučkar Ž. Transplantacija bubrega - 110-godišnja uspješna priča. Acta Medica Croatica. 2012;66 Suppl 2:59-63.

11. Bušić M. Darivanje i presađivanje organa - „Hrvatski model“. Medix. 2011;17:144-148.

12. Knotek M.Transplantacija bubrega. Medix. 2012;18:98-99.

13. Ministarstvo zdravstva i socijalne skrbi. Nacionalni transplantacijski program u 2014. Preliminarno izvješće [internet]. Dostupno na: http://www.zdravlje.hr/ programi_i_projekti/transplantacijski_program/statistika (pristupljeno 03.09.2015.)

14. Hrvatska donorska mreža. Što je istina o crnom tržištu i trgovini ljudskim organima-Mitovi i stvarne prijetnje [internet]. Dostupno na: http://www.hdm.hr/index. php?option=com_content\&view=article\&id=313:to-jeistina-o-crnom-tritu-i-trgovini-ljudskim-organima-mitovi-i-stvarne-prijetnje\&catid=56: etiki-aspekti\&ltemid $=78$ (pristupljeno 05.09.2015.) 


\section{DIFFERENCES IN ATTITUDES TOWARDS ORGAN DONATION BETWEEN HEALTH AND NON-HEALTH PROFESSIONALS IN BJELOVAR-BILOGORA COUNTY}

1 Elvira Jukić

2 Zrinka Puharić

2 Ksenija Eljuga

2 Tatjana Badrov

1 Intensive care unit General hospital Bjelovar

2 Technical college Bjelovar, Study of nursing receive organs regardless of the person's age, gender, race or religion. Despite the small number of signed donor cards, most of the participants expressed a wish to donate their organs, which indicates the importance of education and encouraging people to sign donor cards, if this is in accordance with their attitude.

\begin{abstract}

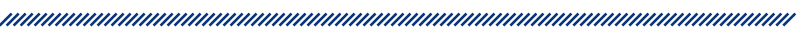

The aim of this paper is to find differences in the attitudes of health and non-health professionals towards the issue of organ donation and explore the following: to determine whether there is a difference in the decision about organ donation depending on the participants' profession; examine which factors are important to health or non-health participants if they decided to donate their organs, examine in which conditions would health or non-health participants refuse to donate their organs or refuse to accept the organs of another person. The study included 200 participants, 100 health professionals and 100 non-health professionals. A special questionnaire was designed to examine the attitudes towards organ donation. The results have shown that there is no statistically significant difference in the decision about organ donation depending on the profession of the participants. The participants emphasized the urgency of the patient's condition and the person not being an addict as important factors and conditions for organ donation, while stating that they would
Keywords: organ donation, donor card, health professionals 